\title{
The Determinants of Bank Interest Margins: A Short-term Funding Perspective
}

\author{
Ming $\mathrm{Qi}^{1}$, \& Yumo Yang ${ }^{1}$ \\ ${ }^{1}$ School of Business Administration, China University of Petroleum (Beijing), Beijing, China. \\ Correspondence: Ming Qi, School of Business Administration, China University of Petroleum (Beijing), Beijing, China.
}

Received: September 29, 2016

Accepted: October 14, 2016

Available online: October 31, 2016

doi:10.11114/aef.v4i1.1902

URL: http://dx.doi.org/10.11114/aef.v4i1.1902

\begin{abstract}
The net interest margins (NIM) is one of the key metrics for Banks, and for those who want to evaluate the performance of a bank's investments. In this paper, the determinants of net interest margins of China's financial institutions are investigated, while taking into account the effects of short-term funding and the presence of foreign banks. By distinguishing different shareholding structure and comparing the banks' net interest margins before and after the banking liberalization, we find that both short-term funding and foreign bank presence have negative impacts on the net interest margins of Chinese domestic banks. The banking sector after the financial liberalization, especially the national wide banks, has better ability to manage the financial stress. The China Construction Banks(CCBs) and Credit Cooperatives suffer higher interest margin decline than State-Owned commercial Banks(SOBs) and Joint Stock Banks(JSBs). The national wide banks need to accelerate the business diversification and increase the intermediary revenue.
\end{abstract}

Keywords: bank margins, short-term funding, liberalization, risk exposure

\section{Introduction}

The net interest margins (NIM) is commonly defined as the ratio of net interest spread to total assets. It is an important measure of not only bank profitability but also the social cost of financial intermediations. (Demirguc-Kunt and Huizinga 1999; Maudos and Guevara 2004) Higher interest margins bring about a higher profitability and better stability for the banking sector, especially for a non well-functioning economy. It may be necessary for the financial intermediaries to be insulated from financial shocks. (Gorton and Winton 1998;Saunders and Schumacher 2000) Shown in Table1 are the net interest margins for a sample of banks over the period $2000-2009$ in China. We find the NIM of Chinese banks keeps increasing until 2009, in which year the influence of financial crisis has spread to China. The CCBs and cooperatives credits obtain a higher spread than that of SOBs and JOBs after 2005. Meanwhile, the rising NIM is accompanied by an increased market competition. The main objective of this paper is to investigate the determinants of net interest margins of financial institutions in China while taking into account the effects of short-term funding and the presence of foreign banks.

Ho and Saunders (1981) proposed the pioneering model to study the bank interest margin. A bank is regarded as a risk-averse dealer, and the spread relies on the intermediation activities. The dealership model is a reference framework for many empirical works. Allen (1988) extended the Ho-Saunders dealership model by including alternative products in the loan portfolio, which leads to the diversification benefits of financial intermediaries. Wong (1997) proposed a firm model in a static setting. He analyses multiple risk measures and suggested an ambiguous effect of the interest risk within the interbank market. Angbazo (1997) studied different risk measures and test the impact of short-term assets on different types of banks. He concluded that the default risk, rather not the interest rate risk, has a greater impact on the interest margin of large banks, which have a higher level of short-term assets and hedging instruments. In addition, both the interest rate and liquidity risks are related to the off-balance sheet exposure. Another extension of Ho-Saunders model is proposed by Maudos and Guevara (2004). They widened the original model by including the effects of operating cost and Lerner index, which is a direct measure of market power. They find that the falling operating costs and credit risk contribute to the reduction of bank interest margins.

We extend the dealer model by Ho-Saunders (1981) by including the short term funding ratio. Angbazo (1997) uses the short-term funding to proxy the interest risk, and finds its negative effect on local, regional and super-regional banks. In 
our sample, a great difference of short term funding ratio (short_ratio) between SOBs \& JSBs and CCBs \& cooperative credits is documented between 2000 and 2009. We investigate to what extent the short_ratio affects the net interest margins for these two subgroup banks. During the period 2002 to 2009, the short-term funding of Chinese banks has moved more volatile than the long-term one (see Figure 1). After 2006, foreign banks are allowed to accept money deposits without special licenses. As a consequence, a sharp decline of short-term funding for domestic banks in 2006 is observed. With the sharp increase in banks' reserve ratio in 2007, a large amount of liquidity was frozen in the central bank. Therefore, banks need to maintain the liquidity through short-term funding. The Chinese banks absorbed a large amount of short-term funding through the short-term investment products with the promised high-return. The maturity of this kind of products ranges from 7 days to half a year, which is similar to the interbank loans. The aim of these investment products is to avoid financial distress through money market operations. The latest decline of short-term funding happened in 2008, when the effects of the financial crisis arrived in China as well. The required reserve ratio in 2008 declined considerably compared with that in 2007. As a result, the demand of short term funding also fell in 2008. The following growth of short-term funding in 2009 was associated with the easy credit policy and the loan expansion. However the long-term funding is resistant to the foreign entry. García-Herrero et al. (2009) investigated the Chinese banking sector and attributed the low profitability to the low efficiency of state-owned commercial banks and development banks. By contrast, the market-oriented banks are more profitable. Similarly, Ferri (2009) also documented worse performance of state-owned banks than that of city commercial banks.Bank profitability, cost efficiency, banking sector development, stock market development and inflation have positive relationship in China. Low profitability can be explained by higher volume of non - traditional activity and higher taxation. (Tian and Floros, 2012) Fu et al. (2014) examine competition and stability in Asia-Pacific banking over 2003-2010 and confirm that Concentration fosters fragility, lowers pricing power and induces risk-taking. Tougher entry restrictions benefits banking sector stability. Wang et al. (2014) evaluate efficiencies of the Chinese commercial banks and find that the Chinese banking reform improves its overall efficiency over the study period. The main contribution of this paper is to extend the classical Ho-Saunders (1981) by introducing the short term funding ratio, and empirically test the real effects of short term funding on banks' profitability. In spite of a notable reform, the competitive structure of Chinese banking sector is little improved and an easier market entry needs to be encouraged. (Fu and Heffernan 2009). On the other hand, an increased presence of foreign banks contributes to the improvement of competition in the banking sector and reduces the interest margins of domestic banks. (Claessens et al. 2001; Williams 2003) By focusing on the net interest margins of banks in two sub-periods, - before and after the financial market openness in 2007 - we attempt to investigate the impact of the deregulation process and the presence of foreign banks on the profitability of Chinese banking sector. The contribution of this paper to the related literature is twofold. First, we widen the dealer model proposed by Ho and Saunders and investigate the real effect of short-term funding ratio on bank interest margins. Second, we use a comprehensive data set of Chinese financial intermediations for the estimation. By dividing the sample in different periods and types, we examine the real effect of financial openness on the banking sector and different ownerships.

The movements of short- and long- term funding

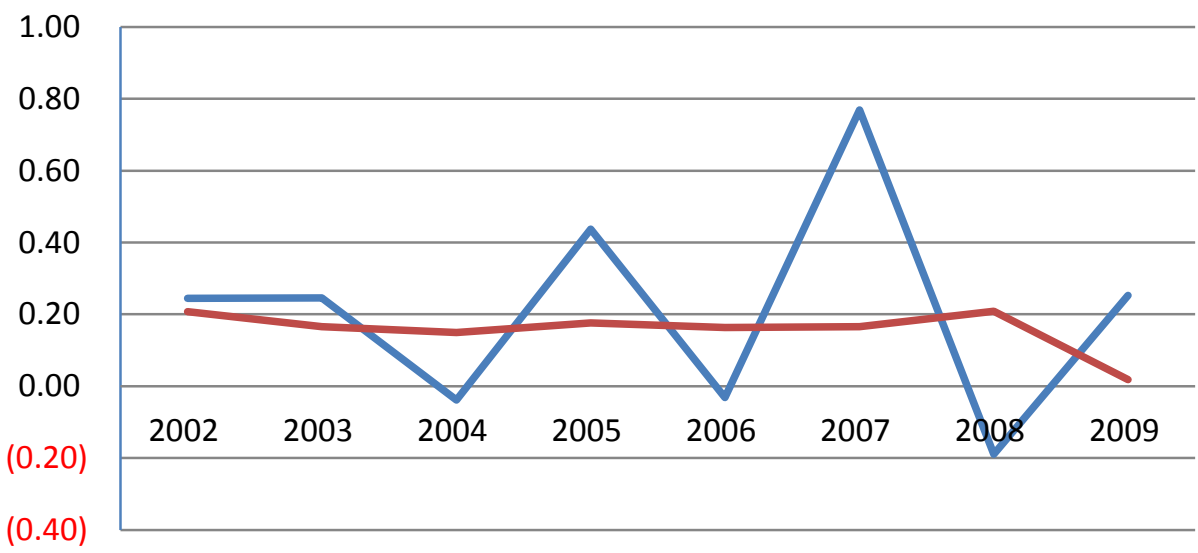

Change of short-term funding Change of long-term funding

Figure 1. The Movements of Short and Long-Term Funding 


\section{Method}

\subsection{Theoretical Framework}

The original Ho-Saunders model relies on pure customer deposits-lending behavior. The interest rates on deposits $\left({ }^{r_{D}}\right)$ and loans $\left({ }^{r_{L}}\right)$ are determined exogenously by immediate services fees a and $\mathrm{b}$, which are set by the banks. Then the unit margin or spread $\mathrm{s}$ is expressed as $s=r_{L}-r_{D}=a+b$. We extend this model by assuming the total deposits consist of both customer deposits (D) and the short term funding(C) from the money market. The short-term funding is an important instrument for banks to overcome temporary setbacks or cash-flow issues. Differing from the loan and deposits, the rate of short-term borrowing is the bank's opinion of the "true" price $r$ plus c, which is paid out for the immediate provision of funding. The rate of customer deposits and short-term funding, denoted as $r_{D}$ and $r_{S F}$ are defined as:

$$
\begin{aligned}
& r_{D}=r-a \\
& r_{S F}=r+c
\end{aligned}
$$

The proportion of customer deposits to total deposit \& short-term funding is denoted as $\rho$, and accordingly the proportion of short term funding is $1-\rho$. Since the banks need to payout interests for their short term funding (borrowing), we propose a new framework for loan and total deposit \& short-term funding, $r_{L}$ and $r_{D \& S F}$, as follows:

$$
\begin{aligned}
& r_{L}=r+b \\
& r_{D \& S F}=\rho \cdot(r-a)+(1-\rho) \cdot(r+c)=r-\rho \cdot a+(1-\rho) \cdot c \\
& s=r_{L}-r_{D \& S F}=(r+b)-[r-\rho \cdot a+(1-\rho) \cdot c]=a+b-(1-\rho)(a+c)
\end{aligned}
$$

The expression of interest spread $s$ implies that the higher proportion of short-term funding, the lower spread expected. In addition, the probability of a new funding arriving at the bank increases with their willingness to pay for the interest $c$. Since the bank pays an extra fee for the short-term funding, the higher rate the bank would like to pay, the higher probability she can obtain a new funding from the money market. In other words, by raising $c$, which is the rate (price) of short-term funding, $r_{S F}$ rises, and new short-term funding is encouraged. By means of Taylor series of banks' expected utility, we get the margin as follows: The derivation process of following formulas are presented in the appendix.

$$
\begin{aligned}
& a+b=\frac{\alpha}{\beta}+\frac{1}{2} R \sigma_{I}^{2} Q \\
& a+c=\frac{\alpha}{\beta}+\frac{1}{2} R \sigma_{I}^{2}\left(Q+2 I_{0}\right)
\end{aligned}
$$

From the results above we find the bank's unit margin of pure intermediation service, i.e. $a+b$, is the same as that in original Ho-Saunders Model. Therefore, we argue that if the short-term funding is involved in the portfolio, the bank suffers a lower net interest margin, which is expressed as follows:

$$
s=a+b-(1-\rho)(a+c)=\rho\left(\frac{\alpha}{\beta}+\frac{1}{2} R \sigma_{I}^{2} Q\right)-(1-\rho) R \sigma_{I}^{2} I_{0}
$$

It tells us that the interest margin s increases with the customer deposits and decreases with the proportion of short-term funding.

\subsection{Empirical Framework}

There are two empirical approaches to estimate the net interest margin. The first one is two-stage process, which is used by Ho and Saunders (1981), Saunders and Schumacher (2000) and Doliente (2005). In the first stage, a cross-sectional regression is run to obtain a measure of the "pure" spread for each country's banking section. In the second stage, the "pure" spread is regressed against the volatility of interest rates. The introduction of "pure" interest margin is an 
advantage of this approach, although a long time series is required for the second stage estimation.

On the other hand, Angbanzo (1997) propose a single-stage approach to estimate the determinants of net interest margin. The bank-specific characteristics and country-specific macroeconomic conditions are employed as explanatory variables. Since our sample covers annual accounting data between the years 2000-2009. we employ the single-step estimation approach to test our hypotheses. In the empirical model, we include (a) bank specific variables, such as the loan size, opportunity, inefficiency, short_ratio and different risk measures. (b) country-specific market characteristic, i.e. HHI and (c) the year dummy. In model I we use a single-step approach and include bank specific variables and market concentration index for the estimation. In model II, the number of foreign banks is involved in the framework in order to capture the effect of foreign banks' presence. Our empirical framework is specified as follows:

Model I:

$$
\begin{aligned}
\text { NIM }_{i t}= & \beta_{0}+\beta_{1} \text {HHI }_{t}+\beta_{2} \text { Size }_{i t}+\beta_{3} \text { Opportunity }_{i t}+\beta_{4} \text { Inefficiency }_{i t}+\beta_{5} \text { Short_Ratio }_{i t} \\
& +\beta_{6} \text { Risk_Aversion }_{i t}+\beta_{7} \text { Liquid__Risk }_{i t}+\beta_{8} \text { Credit_Risk }_{i t}+\text { Year }_{i}+\varepsilon_{i t}
\end{aligned}
$$

Model II:

$$
\begin{aligned}
\text { NIM }_{i t}= & \beta_{0}+\beta_{1} \text { HHI }_{t}+\beta_{2} \text { Size }_{i t}+\beta_{3} \text { Opportunity }_{i t}+\beta_{4} \text { Inefficiency }_{i t}+\beta_{5} \text { Risk_Aversion }_{i t} \\
& +\beta_{6} \text { Liquid_Risk }_{i t}+\beta_{7} \text { Default_Risk }_{i t}+\beta_{8} \text { Credit_Risk }_{i t}+\beta_{9} \text { Foreign }_{i}+\varepsilon_{i t}
\end{aligned}
$$

We estimate the results by using the Generalized Least Squared (GLS) with heteroskedastic and autocorrelation structure. The year dummy is included in the regression to control for unknown period effects. According to the econometric approach presented above, we include the following variables:

HHI: we use the Herfindahl-Hirschmann Index (HHI) to capture the competitive structure of the market. In spite of some evidence of positive impact of HHI on the interest margin (Maudos and Guevara 2004; Carbó-Valverde S. and F. Rodriguez-Fernandez (2007), Cetorelli and Gambera (2002) argue that the bank concentration can also impose depressing impact on the growth.

Size: The log of total loans is used as a proxy of the size of individual bank. It is expected to have negative impact on the interest margin. (Kasman et al. 2007)

Opportunity: We use the ratio of liquid reserves which are the sum of cash and due from banks, to total assets to proxy the opportunity costs of bank reserves. (Maudos and Guevara 2004)

Inefficiency: This variable is proxyed by the cost_to_income_ratio. The interest margin is undermined by high costs, which is associated with high efficiency. Therefore, a negative sign is expected.

Short_Ratio: In previous studies, the short term funding is associated with the interest risk. (Angbazo 1997) We employ the ratio of short term funding to total deposits \& short-term funding to proxy the short_ratio of individual banks. According to the theoretical analyses in section 3, a higher short_ratio implies higher interests payment, which will reduce the net interest margin of banks. Therefore, a negative impact of the short_ratio is expected.

Risk_Aversion: Following McShane and Sharpe (1985), Maudos and Guevara (2004), this variable is proxied by the ratio of total equity to total assets. Since the higher interest margin is favored by those banks who are more risk averse, a positive sign is expected

Liquid_Risk: Following Angbazo (1997), we propose the ratio of liquid assets to total liabilities, i.e. total deposits and borrowing, to proxy the liquid risk. A positive sign is expected for this variable.

Credit_Risk: We use the loan to total assets ratio to estimate the credit risk. (Maudos and Guevara 2004 and Kasman et al. 2010) Since the higher volume of loans granted is associated with higher credit risk exposure, we assume that it has a positive impact on the interest margin.

Default_Risk: Following Kasman et al. 2010, we use the ratio of loan loss provisions to total loans to proxy the default risk of individual bank. Since the banks require an extra interest margin to compensate for higher default risk, a positive sign is expected.

\section{Data and the Description of the Sample}

We use a sample of 116 Chinese domestic banks, which consists of State-Owned commercial Banks (SOBs); Joint Stock Banks (JSBs); City Commercial Banks(CCBs) and Credit Cooperatives. All bank-level data in the sample are obtained from the Bureau Van Dijk's BankScope database. The sample includes annual information for an unbalanced 
panel of 1,113 observations over the period 2000-2009. The data set is divided into two sub-periods - before and after 2007 - and two subgroups - SOBs \& JCBs and CCBs \& Credit Cooperatives. According to the WTO accession agreement, China began to open the domestic Banking market from November 2006. Foreign-funded banks were allowed to operate RMB business in mainland China. Therefore, the period after 2007 is denoted as the post-liberalisation period. In addition, the full sample is divided into another two groups: SOBs \& JCBs, which are characterised by nationwide branches and business; and CCBs \& Credit Cooperatives, which are more focused in reginal based market.

The table 1 illustrates the mean value of net interest margin of Chinese banks in each year. We find that the NIM of domestic banks keeps increasing until 2008, when the influence of financial crisis has spread to China. In terms of the market competition, the Herfindahl-Hirschman Index is observed to be decreasing from 2000 to 2006, and then it began to rise slowly. The loan size keeps stable and SOBs \& JSBs issued higher volume of loans than CCBs \& cooperative credits. The opportunity costs of all financial intermediaries are declining smoothly until 2007 and then probe a sharp spike in 2008 and 2009. It can be largely attributed to the soaring liquid reserves of CCBs \& cooperative credits, which are more risk-averse and prefer to leave aside more liquid reserves to resist the financial risk. However, they have a considerably higher level of short term funding than that of SOBs \& JSBs. Finally, the presence of foreign banks keeps growing during the whole sample period.

The summary statistics of sub-period and sub-type groups are illustrated in Table 2. The net interest margin of the sample 2007 - 2009 is higher than that before 2007. It means that the domestic banks do not suffer from the financial market openness in 2007. Instead, the presence of foreign banks, the number of which increases from 196 to 308, has forced domestic banks to improve their efficiency and performance. The inefficiency of sample $2007-2009$ is only $67 \%$ of that of sample $2000-2006$. In addition, we find that after 2007, the opportunity costs of bank reserves has increased substantially - from $0.7 \%$ to $4 \%$. Meanwhile, the short ratio decreased from $9.9 \%$ to $7.5 \%$ after 2007 . They might contribute to the rise of interest margins after the financial market openness. On the other hand, the results of sub-type groups imply that the CCBs \& Credit Cooperatives enjoy a relative higher interest margin than SOBs \& JSBs, although they granted lower volume of loans. And they hold more opportunity reserves $(2.3 \%)$ and a higher short ratio $(9.8 \%)$, compared with SOBs \& JSBs. Besides these, we do not observe significant change of other variables including the fundamental risk ratios.

Table 1.The Mean Value of Net Interest Margin of Chinese Banks in Each Year

\begin{tabular}{|c|c|c|c|c|c|c|c|c|c|c|}
\hline Year & 2000 & 2001 & 2002 & 2003 & 2004 & 2005 & 2006 & 2007 & 2008 & 2009 \\
\hline \multicolumn{11}{|c|}{ Panel I: The whole sample } \\
\hline NIM (\%) & 1.88 & 2.12 & 2.02 & 2.01 & 2.31 & 2.64 & 2.83 & 3.22 & 3.40 & 2.81 \\
\hline HHI & 1570.15 & 316.84 & 237.58 & 208.31 & 162.99 & 125.59 & 101.60 & 107.73 & 134.43 & 149.16 \\
\hline Size & 8.02 & 8.57 & 8.40 & 8.46 & 8.29 & 8.12 & 7.90 & 8.13 & 8.82 & 9.21 \\
\hline Opportunity (\%) & 1.29 & 1.07 & 0.75 & 0.68 & 0.60 & 0.58 & 0.69 & 0.96 & 5.25 & 7.36 \\
\hline Short_Ratio (\%) & 3.37 & 10.61 & 14.10 & 11.94 & 10.03 & 8.28 & 8.24 & 8.32 & 7.08 & 6.64 \\
\hline Foreign banks & 191 & 190 & 181 & 192 & 188 & 207 & 224 & 274 & 311 & 338 \\
\hline \multicolumn{11}{|c|}{ Panel II: The sample for SOBs and JSBs } \\
\hline NIM (\%) & 2.08 & 2.30 & 2.23 & 2.27 & 2.37 & 2.42 & 2.46 & 2.82 & 2.86 & 2.23 \\
\hline Size & 12.47 & 10.52 & 10.83 & 11.10 & 10.75 & 10.97 & 10.94 & 11.15 & 11.39 & 11.61 \\
\hline Opportunity (\%) & 1.17 & 1.38 & 0.89 & 0.69 & 0.47 & 0.43 & 0.46 & 0.48 & 0.31 & 0.27 \\
\hline Short_Ratio (\%) & 0.36 & 8.62 & 7.22 & 7.07 & 6.09 & 5.94 & 5.16 & 6.78 & 7.91 & 6.23 \\
\hline \multicolumn{11}{|c|}{ Panel III: The sample for CCBs and cooperative credits } \\
\hline NIM (\%) & 1.806 & 1.98 & 1.91 & 1.89 & 2.29 & 2.70 & 2.91 & 3.31 & 3.57 & 3.01 \\
\hline Size & 6.23 & 7.12 & 7.13 & 7.33 & 7.40 & 7.39 & 7.25 & 7.44 & 8.04 & 8.42 \\
\hline Opportunity (\%) & 1.34 & 0.85 & 0.67 & 0.67 & 0.64 & 0.62 & 0.73 & 1.06 & 6.93 & 10.00 \\
\hline Short_Ratio (\%) & 4.58 & 12.25 & 17.92 & 14.09 & 11.55 & 9.16 & 8.97 & 8.73 & 6.75 & 6.78 \\
\hline
\end{tabular}

Note: Since the value of HHI and Foreign bank numbers for Panel II and Panel IIIare the same as that of Panel I, we do not report them in the sub-group results. 
Table 2. Summary Statistics by the Group of Year and Type

\begin{tabular}{|c|c|c|c|c|c|c|c|c|}
\hline \multirow{2}{*}{ Variables } & \multicolumn{2}{|c|}{ Sample $(2000-2006)$} & \multicolumn{2}{|c|}{ Sample (2007 - 2009) } & \multicolumn{2}{|c|}{ Sample ( SOBs \& JSBs) } & \multicolumn{2}{|c|}{ Sample (CCBs \& Others) } \\
\hline & Mean & Std. dev & Mean & Std. dev & Mean & Std. dev & Mean & Std. dev \\
\hline \multicolumn{9}{|c|}{ Dependent Variable } \\
\hline NIM (\%) & 2.426 & 0.847 & 3.164 & 0.990 & 2.448 & 0.444 & 2.805 & 1.080 \\
\hline \multicolumn{9}{|c|}{ Explanatory Variables } \\
\hline $\mathrm{HHI}$ & 388.636 & 486.930 & 130.383 & 17.167 & 312.342 & 426.495 & 310.629 & 423.790 \\
\hline Size & 8.201 & 1.922 & 8.655 & 1.043 & 11.063 & 1.479 & 7.525 & 1.030 \\
\hline Opportunity (\%) & 0.7 & 0.007 & 4 & 0.070 & 0.6 & 0.009 & 2.3 & 0.051 \\
\hline Inefficiency (\%) & 49.4 & 0.169 & 37.3 & 0.102 & 44.8 & 0.179 & 44.6 & 0.150 \\
\hline Short Ratio (\%) & 9.9 & 0.105 & 7.5 & 0.075 & 6.7 & 0.090 & 9.8 & 0.096 \\
\hline $\begin{array}{l}\text { Risk Aversion } \\
(\%)\end{array}$ & 4.3 & 0.025 & 5.9 & 0.024 & 4.2 & 0.039 & 5.2 & 0.019 \\
\hline Liquid Risk (\%) & 18.8 & 0.085 & 24.1 & 0.089 & 20 & 0.098 & 21.3 & 0.087 \\
\hline Default Risk (\%) & 0.009 & 0.006 & 0.009 & 0.008 & 0.7 & 0.004 & 1.0 & 0.007 \\
\hline Credit Risk(\%) & 54.5 & 0.096 & 52.8 & 0.081 & 57.3 & 0.090 & 52.8 & 0.089 \\
\hline Foreign & 196 & 13.511 & 308 & 26.260 & 229 & 53.964 & 229 & 54.385 \\
\hline
\end{tabular}

\section{Empirical Results}

We present the regression results for model I, without the influence of foreign banks, in Table 3. The results for model II, with the influence of foreign banks, are shown in Table 4. The explanatory variables of our unbalance panel are estimated by Generalized Least Squares (GLS), by which autocorrelation and heteroskedasticity across panels are controlled. The time-specific dummies are introduced to capture the influence explanatory variables particular to each time period. Table 3 summarises the impact of the explanatory variables on the net interest margin for the whole sample and different subsamples. Column (1) shows the estimation results of pooled financial institutions during the entire research period. Column (2) and (3) illustrate the results of pooled financial institutions before the financial market openness - in Column (2), and after the financial market openness, Column (3), respectively. Since banks in different types tend to run their business also in different ways, we also report the results for the subsample of SOBs \& JSBs and CCBs \& Credit Cooperatives in Column (4) and (5) respectively.

The results illustrate that in general the explanatory variables are statistically significant and present the predicted signs. The short funding ratio is one of the most important variables in explaining the net interest margins. It presents a predicted negative sign and high significant level for all samples. This result confirms the undermining effect of short term funding on banks' profitability and consists with the results of Angbazo (1997). It can be attributed to the higher volume of short funding for these two subgroups. So we confirm our hypothesis 1 that the short-term funding has a negative impact on the net interest margin for all kinds of financial institutions. The higher short term ratio, the lower bank spreads. This negative impact is particularly higher for the sub-period sample before 2007 and for CCBs \& Cooperatives. It implies that the banking sector before the financial market openness, especially the regional based banks, suffers more from the short term funding. The loan size has a negative and statistically significant impact on the net interest margin for the pooled sample and two sub-period samples. It implies that over our research period, credit expansion brings about a declining profitability in terms of interest business. This result is in line with that of Zhou and Wong (2008), Hawtrey and Liang (2008), Kasman et al. (2010). Since the interest rate policies is to a large extent controlled by the supervisor, loan expansion is the main mean to earn interest margins. The net interest margin is more associated with the rising volume of commercial loans. The lower NIM is then attributed to the economic stimulus plan and credit boom after the breakout of financial crisis in 2008. The opportunity cost measured by the ratio of liquid reserves has a statistically significant positive impact on net interest margins for the pooled sample. This result implies that the high liquidity reserves is underpinned by greater interest margins, which confirms the finding of Maudos and Guevara (2004). This phenomenon is particularly significant for financial institutions after the financial market openness in 2007 and regional-based banks, e.g. CCBs \& Credit Cooperatives.

In terms of risks premium effect, the credit risk deserves special mention, which has positive and statistically significant impact on all samples. Taking into account the interest rate control in China, the self-price rights of Chinese banks are 
limited. This result suggests that all kinds of financial institutions obtain a higher interest margin to compensate for the credit risk exposure. It supports the findings of Maudos and Guevara (2004), Hawtrey and Liang (2008) and Kasman et al (2010). In addition, we document a higher coefficient for the sample after the year 2007 and for CCBs \& Credit Cooperatives. It implies that the financial market openness has objectively forced domestic bank to improve their profitability to overcome higher credit risk, and it is particularly necessary for those regional-based banks. The ratio of equity to assets as a proxy of risk averse has a predicted positive and significant impact on the net interest margin, especially for CCBs \& Credit Cooperatives. This result is in line with the findings of Maudos and Guevara (2004) and supports the theoretical analysis of Wang (1997). In addition, the net interest margins of CCBs \& Credit Cooperatives are estimated to increase with the liquid risk and default risk. These results confirm the findings of Angbazo (1997) and Drakos (2003). It can be explained by the fact that the regional based financial institutions tend to put aside higher volume of liquid assets and loan provisions to overcome the potential risks. In a nutshell, the banking sector in China, after the financial openness in 2007, holds a higher volume of liquid reserves and suffered less from the short term funding than that before the openness. Although this is mainly caused by the frequently raised deposit reserve ratio, it suggests a higher risk aversion of the banking sector after the financial crisis. We also compare the profitability of national wide banks, e.g. SOBs \& JCBs, with that of regional-based banks, e.g. CCBs \& Credit Cooperatives. We find that regional-based banks obtain higher net interest margins from their risk taking behavior and suffer lower from short term funding than national wide banks.

In Table 4 we include the number of foreign banks to proxy the influence of foreign bank presence. We find the presence of foreign banks has a significant negative effect on the banking sector, particularly after the financial market openness in 2007. It implies that the entry of foreign banks, especially after 2007, has rendered the domestic bank market more competitive and therefore reduces bank's net interest margins. From December 2006, foreign banks are allowed to run business in China. Compared with domestic banks, foreign banks were more mature and experienced in retail business and strong technical support. Not only on traditional business such as loans and deposits, foreign financial institutions compete fiercely on financial service as well, such as settlement and personal retail banking.They increased their market shares by taking advantage of their strength in product creation and wealth management. This poses a great threat to domestic banks, unless they increase their operations and improve their efficiency. Their competition has a major impact on domestic banks in the fields of personal banking and wealth management. Considering the increasing competition by foreign rivals, the "legally protected" profits of domestic banks are unsustainable. Before the openness of banking sector, the presence of foreign banks cannot threaten the domestic banks. The "legally protected" interest margins contribute to the profits of domestic banks. However, the openness of foreign banks brings about new competitors and foreign financial innovations. This results is consistent with the findings of Claessens et al. (2001) and Claeys and Vennet (2008). The negative coefficient for the subsample of CCBs \& Credit Cooperatives is much higher than others. It suggests that the foreign banks compete mainly with those banks which focus on regional business. On the other hand, the presence of foreign banks imposes relative lower impact on national wide banks, e.g. SOBs \& JCBs. The financial liberalization and new entrant in banking sector promoted the competition in banking sector and forced banks to pay more attention to the cost efficiency as they involve more financial innovation. Giant financial institutions have better access to advanced management systems and more experience to compete with foreign banks. Therefore, SOBs \& JCBs has better resistance to foreign entrants.

\section{Conclusions and Policy Implications}

In this paper, we investigate the determinants of net interest margins of China's banking sector, as well as the impact of short term funding and foreign bank presence over the period of $2000-2009$. To obtain a clear picture of the financial market openness and banks' diversity, we also compare the results of banks in different subsamples, e.g. before and after the financial openness, SOBs \& JCBs and CCBs \& Credit Cooperatives. Our findings suggest that both the short term funding and foreign bank presence impose negative impacts on the net interest margins of Chinese domestic banks. The banking sector after the financial market openness, especially the national wide banks, has better ability to manage the financial stress. The presence of foreign banks brought about higher banking competition and made the net interest margins narrower. The credit risk is the major measure to force the banking sector enhancing their profitability. The regional based banks achieved higher interest margins than national wide banks to compensate for risk exposures. And we find that the loan size has a statistically significant negative effect on the net interest margins over our research period. Obviously, considering the high-speed credit expansion in China, this extensive pattern of growth is rather not sustainable. How to effectively control the credit scale and promote the interest profitability is another problem crying out for solutions after the crisis. An interest rate liberalization reform and flexible competition pattern are needed to be introduced to Chinese banking sector. And the CCBs and Credit Cooperatives suffer higher interest margin reduction than SOBs \& JSBs. The national wide banks need to accelerate the business diversification and increase the intermediary business revenue. 
Table 3. Regression Results for Pooled Sample, Two Sub-Periods, and Two Sub-Groups.

\begin{tabular}{|c|c|c|c|c|c|}
\hline & \multicolumn{5}{|c|}{ Dependent variable: Net Interest Margin (NIM) } \\
\hline & (1) & (2) & (3) & (4) & (5) \\
\hline \multirow[t]{2}{*}{$\mathrm{HHI}$} & -0.0000139 & -0.00004 & $-0.086^{*} \cdot k_{k}$ & 0.0000145 & -0.167 *2* $k^{*}$ \\
\hline & $(-0.18)$ & $(-0.68)$ & $(-16.49)$ & $(0.24)$ & $(-5.73)$ \\
\hline \multirow[t]{2}{*}{ Size } & -0.0561 *k水 & $-0.0548 * *$ & $-0.0503^{* * * *}$ & 0.0111 & -0.0288 \\
\hline & $(-4.23)$ & $(-2.41)$ & $(-2.63)$ & $(0.38)$ & $(-1.04)$ \\
\hline \multirow[t]{2}{*}{ Opportunity } & $5.767 * * *$ & 3.776 & $5.963^{*} * \cdots$ & 2.925 & $8.340^{\text {*k* }}$ 列 \\
\hline & $(5.47)$ & $(1.35)$ & $(6.43)$ & (1.17) & $(12.90)$ \\
\hline \multirow[t]{2}{*}{ Inefficiency } & -0.247 & -0.582 & 0.472 & -0.273 & -0.166 \\
\hline & $(-0.83)$ & $(-1.34)$ & $(0.97)$ & $(-0.64)$ & $(-0.36)$ \\
\hline \multirow[t]{2}{*}{ Short_ratio } & $-2.114^{*}$ 水水 & -2.271 *** & $-0.945 *$ & $-1.862 * * *$ & -4.058 ***⿰㇇⿰亅⿱丿丶丶 \\
\hline & $(-6.30)$ & $(-5.25)$ & $(-1.83)$ & $(-5.03)$ & $(-11.62)$ \\
\hline \multirow[t]{2}{*}{ Risk_aversion } & $1.835 * *$ & 1.468 & 0.369 & 0.912 & $10.21^{* k * k}$ \\
\hline & (1.99) & (1.09) & $(0.39)$ & $(1.08)$ & $(7.61)$ \\
\hline \multirow[t]{2}{*}{ Liquid_risk } & 0.0709 & 0.566 & -0.0160 & -0.0635 & $0.781^{* * *}$ \\
\hline & $(0.31)$ & $(1.20)$ & $(-0.05)$ & $(-0.40)$ & $(2.32)$ \\
\hline \multirow[t]{2}{*}{ Default_risk } & 1.260 & 2.324 & $1.241 *$ & 0.502 & $28.48^{*}$ 水水 \\
\hline & $(0.78)$ & $(0.91)$ & (1.81) & $(0.33)$ & (7.19) \\
\hline \multirow[t]{2}{*}{ Credit_risk } & $1.470^{*}$ *k* & $1.436^{* * * * *}$ & $1.916^{* * * *}$ & 0.631 & 4.129 水水 \\
\hline & $(5.32)$ & (3.99) & $(4.23)$ & (1.49) & (13.95) \\
\hline \multirow[t]{2}{*}{ Constant } & $2.256^{* * * *}$ & $2.594^{* * * *}$ & $96.04^{* 2 * \cdots}$ & 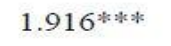 & 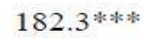 \\
\hline & $(8.40)$ & $(7.48)$ & (18.33) & (3.49) & $(5.75)$ \\
\hline $\mathrm{N}$ & 232 & 110 & 100 & 113 & 119 \\
\hline
\end{tabular}

Notes: Autocorrelation within panels and heteroskedasticity across panels are controlled. The time-specific dummies are introduced into the regression. $t$ statistics in parentheses $* \mathrm{p}<0.10, * * \mathrm{p}<0.05, * * * \mathrm{p}<0.01$

Table 4. Regression results for pooled sample, two sub-periods, and two sub-groups by including the presence of foreign banks.

\begin{tabular}{lccccc}
\hline \multicolumn{5}{c}{ Dependent } & \multicolumn{5}{c}{ variable: Net Interest Margin (NIM) } \\
& $(1)$ & $(2)$ & $(3)$ & $(4)$ & $(5)$ \\
\hline HHI & $-0.000746^{* * *}$ & -0.0000168 & $-0.0179 * * *$ & $-0.000902 * * *$ & $-0.0415^{* * *}$ \\
Size & $(-7.04)$ & $(-0.25)$ & $(-12.45)$ & $(-8.25)$ & $(-5.10)$ \\
& $-0.0561^{* * *}$ & $-0.0548^{* *}$ & $-0.0503 * * *$ & 0.0111 & -0.0288 \\
Opportunity & $(-4.23)$ & $(-2.41)$ & $(-2.63)$ & $(0.38)$ & $(-1.04)$ \\
& $5.767 * * *$ & 3.776 & $5.963 * * *$ & 2.925 & $8.340 * * *$ \\
Inefficiency & $(5.47)$ & $(1.35)$ & $(6.43)$ & $(1.17)$ & $(12.90)$ \\
& -0.247 & -0.582 & 0.472 & -0.273 & -0.166 \\
Short_ratio & $(-0.83)$ & $(-1.34)$ & $(0.97)$ & $(-0.64)$ & $(-0.36)$ \\
& $-2.114 * * *$ & $-2.271 * * *$ & $-0.945 *$ & $-1.862 * * *$ & $-4.058^{* * *}$ \\
Risk_aversi & $(-6.30)$ & $(-5.25)$ & $(-1.83)$ & $(-5.03)$ & $(-11.62)$ \\
on & $1.835 * *$ & 1.468 & 0.369 & 0.912 & $10.21 * * *$ \\
& & & & & \\
Liquid_risk & $(1.99)$ & $(1.09)$ & $(0.39)$ & $(1.08)$ & $(7.61)$ \\
& 0.0709 & 0.566 & -0.0160 & -0.0635 & $0.781^{* *}$ \\
Default_risk & $(0.31)$ & $(1.20)$ & $(-0.05)$ & $(-0.40)$ & $(2.32)$ \\
& 1.260 & 2.324 & $1.241 *$ & 0.502 & $28.48 * * *$ \\
& $(0.78)$ & $(0.91)$ & $(1.81)$ & $(0.33)$ & $(7.19)$
\end{tabular}




\begin{tabular}{lccccc} 
Credit_risk & $1.470^{* * *}$ & $1.436^{* * *}$ & $1.916^{* * *}$ & 0.631 & $4.129 * * *$ \\
& $(5.32)$ & $(3.99)$ & $(4.23)$ & $(1.49)$ & $(13.95)$ \\
Foreign & $-0.0207 * * *$ & 0.00334 & $-0.0176^{* * *}$ & $-0.0259 * * *$ & $-0.0323 * * *$ \\
& $(-9.80)$ & $(1.28)$ & $(-16.89)$ & $(-10.22)$ & $(-5.84)$ \\
$\mathrm{N}$ & 232 & 110 & 100 & 113 & 119 \\
\hline
\end{tabular}

Notes: Autocorrelation within panels and heteroskedasticity across panels are controlled. The time-specific dummies are introduced into the regression. $t$ statistics in parentheses $* \mathrm{p}<0.10,{ }^{* *} \mathrm{p}<0.05,{ }^{* * *} \mathrm{p}<0.0$

\section{Acknowledgement}

This work was supported by Beijing Natural Science Foundation under Grant 9164034; Science Foundation of China University of Petroleum, Beijing under Grant 2462013YJRC009.

\section{Reference}

Allen, L (1988). The determinants of bank interest margins: A note, Journal of Financial and Quantitative Analysis, 231-235. http://dx.doi.org/ 10.2307/2330883

Angbazo, L (1997). Commercial bank net interest margins, default risk, interest rate risk and off balance sheet activities, Journal of Banking and Finance , 55-87. http://dx.doi.org/ 10.1016/s0378-4266(96)00025-8

Carbó-Valverde, S., \& Rodriguez-Fernandez, F. (2007). The determinants of bank margins in European banking. Journal of Banking and Finance, 31, 2043-2063. http://dx.doi.org/10.1016/j.jbankfin.2006.06.017

Cetorelli, N., \& Gambera, M. (2001). Banking Market Structure, Financial Dependence and Growth: International Evidence from Industry Data. The Journal of Finance, 56, 617-648. http://dx.doi.org/10.1111/0022-1082.00339

Claessens, S., Demirguc-Kunt, A., \& Huizinga, H. (2001). How does foreign entry affect domestic banking markets? Journal of Banking and Finance, 25, 891-911. http://dx.doi.org/ 10.1016/s0378-4266(00)00102-3

Claeys.,S., \& Vennet, R. V. (2008). Determinants of bank interest margins in Central and Eastern Europe: A comparison with the West. Economic Systems, 32, 197-216. http://dx.doi.org/ 10.1016/j.ecosys.2007.04.001

Demirguc-Kunt, A., \& Huizinga, H. (1999). Determinants of Commercial Bank Interest Margins and Profitability: Some International Evidence. World Bank Economic Review, 13, 379-408.

http://dx.doi.org/10.1093/wber/13.2.379

Drakos, K. (2003). Assessing the success of reform in transition banking 10 years later: an interest margins analysis. Journal of Policy Modeling, 25, 309-317.http://dx.doi.org/ 10.1016/s0161-8938(03)00027-9

Ferri, G. (2009). Are New Tigers supplanting Old Mammoths in China's banking system? Evidence from a sample of city commercial banks. Journal of Banking and Finance, 33, 131-140. http://dx.doi.org/10.1016/j.jbankfin.2007.06.013

Fu, X. M., Lin, Y. R., \& Molyneux, P. (2014). Bank competition and financial stability in Asia Pacific. Journal of Banking \& Finance, 64-77. http://dx.doi.org/10.1016/j.jbankfin.2013.09.012

Fu, X., \& Heffernan, S. (2009). The effects of reform on China's bank structure and performance. Journal of Banking and Finance, 33, 39 - 52. http://dx.doi.org/10.1016/j.jbankfin.2006.11.023

García-Herrero, A., Gavila, S., \& Santabárbara, D. (2009). What explains the low profitability of Chinese Banks? Journal of Banking and Finance, 33, 2080-2092. http://dx.doi.org/ 10.1016/j.jbankfin.2009.05.005

Gorton, G., \& Winton, A. (1998). Banking in Transition Economies: Does Efficiency Require Instability? Journal of Money, Credit and Banking, 30, 621-50. http://dx.doi.org/ 10.2307/2601261

Hawtrey, K., \& Liang, H. (2008). Bank interest margins in OECD countries, The North American Journal of Economics and Finance, 19, 249 - 260. http://dx.doi.org/ 10.1016/j.najef.2008.07.003

Ho, T., \& Saunders, A. (1981). The determinants of bank interest margins: Theory and empirical evidence, Journal of Financial and Quantitative Analysis, 581-600. http://dx.doi.org/ 10.2307/2330377

Kasman, A.; G. Tunc, V. G., \& Okan, B. (2010). Consolidation and commercial bank net interest margins: Evidence from the old and new European Union members and candidate countries. Economic Modelling, 27, 648-655. http://dx.doi.org/ 10.1016/j.econmod.2010.01.004

Maudos, J., \& Fernandez de Guevara, J. (2004). Factors explaining the interest margin in the banking sectors of the 
European Union, Journal of Banking and Finance, 2259-2281. http://dx.doi.org/ 10.1016/j.jbankfin.2003.09.004

Saunders, A., \& Schumacher, L. (2000). The determinants of bank interest rate margins: An international study, Journal of International Money and Finance, 813-832. http://dx.doi.org/10.1016/s0261-5606(00)00033-4

Tan, Y., \& Floros, C. (2012). Bank profitability and inflation: the case of China. Journal of Economic Studies, 675-696. http://dx.doi.org/ 10.1108/01443581211274610

Wang, K., Huang, W., Wu, J., \& Liu, Y. N. (2014). Efficiency measures of the Chinese commercial banking system using an additive two-stage DEA. Omega, 5-20. http://dx.doi.org/10.1016/j.omega.2013.09.005

Williams, B. (2003). Domestic and international determinants of bank profits: Foreign banks in Australia. Journal of Banking and Finance, 27, 1185 - 1210. http://dx.doi.org/10.1016/S0378-4266(02)00251-0

Wong, K. P. (1997). On the determinants of bank interest margins under credit and interest rate risk, Journal of Banking and Finance, 251-271. http://dx.doi.org/10.1016/S0378-4266(96)00037-4

\section{Appendix: Formula Derivation}

$$
\begin{array}{ll}
\text { Deposits: } & r_{D}=r-a ; \\
\text { Short: } & r_{S F}=r-c, \text { with } 0<c<a ; \\
\text { Loan: } & r_{L}=r+b ;
\end{array}
$$

We extend the original Ho-Saunders model by assuming the total deposits consist of both customer deposits (D) and the short term funding $(\mathrm{C})$ from the money market. By introducing the rate of short-term borrowing rSF, which is paid out for the immediate provision of funding, we propose a new framework for loan and total deposit \& short-term funding (Equation 1 -3). The probabilities of new loans, deposit and short-term funding $\left(\lambda_{L}, \lambda_{D}\right.$ and $\left.\lambda_{C}\right)$ are outlined in the following way:

$$
\begin{aligned}
& \lambda_{D}(a)=\alpha-\beta \cdot a \quad \& \cdot \quad \mathrm{c} \\
& \lambda_{L}(b)=\alpha-\beta \cdot b \\
& \lambda_{S F}(c)=\alpha-\beta \cdot c+\vartheta \cdot a
\end{aligned}
$$

Where ${ }^{\alpha, \alpha_{C}, \beta, \beta_{C}, a, b, c>0}$. Our assumption is consistent with original Ho-Saunder model, in which the bank's end-of-period wealth is expressed as:

$$
\text { where } \begin{aligned}
w & =Y+\tilde{I}+C \\
& =\left(1+r_{Y}\right) Y_{0}+Y_{0} z_{Y} \\
I & =\left(1+r_{I}\right) I_{0}+I_{0} z_{I} \\
C & =(1+r) C_{0}
\end{aligned}
$$

The utility of bank depends on all the transactions. The expected utility of wealth can be obtained by using Taylor series expansion:

$$
\begin{aligned}
& E U(w \mid Q=\text { one loan transaction })=u^{\prime}\left(w_{0}\right) b Q+\frac{1}{2} u^{\prime \prime}\left(w_{0}\right)\left(\sigma_{I}^{2} Q^{2}-2 \sigma_{I}^{2} Q I_{0}\right)+u\left(w_{0}\right) \\
& +u^{\prime}\left(w_{0}\right) r_{w} w_{0}+\frac{1}{2} u^{\prime \prime}\left(w_{0}\right)\left(\sigma_{I}^{2} I_{0}{ }^{2}+2 \sigma_{I Y} I_{0} Y_{0}+\sigma_{Y}^{2} Y_{0}^{2}\right) \\
& E U(w \mid Q=\text { one deposit transaction })=u^{\prime}\left(w_{0}\right) a Q+\frac{1}{2} u^{\prime \prime}\left(w_{0}\right)\left(\sigma_{I}^{2} Q^{2}+2 \sigma_{I}^{2} Q I_{0}\right)+u\left(w_{0}\right) \\
& +u^{\prime}\left(w_{0}\right) r_{w} w_{0}+\frac{1}{2} u^{\prime \prime}\left(w_{0}\right)\left(\sigma_{I}^{2} I_{0}^{2}+2 \sigma_{I Y} I_{0} Y_{0}+\sigma_{Y}^{2} Y_{0}^{2}\right) \\
& E U(\bar{w} \mid Q=\text { one short-term funding })=u^{\prime}\left(w_{0}\right) c Q+\frac{1}{2} u^{\prime \prime}\left(w_{0}\right)\left(\sigma_{I}^{2} Q^{2}+2 \sigma_{I}^{2} Q I_{0}\right)+u\left(w_{0}\right) \\
& +u^{\prime}\left(w_{0}\right) r_{w} w_{0}+\frac{1}{2} u^{\prime \prime}\left(w_{0}\right)\left(\sigma_{I}^{2} I_{0}^{2}+2 \sigma_{I Y} I_{0} Y_{0}+\sigma_{Y}^{2} Y_{0}^{2}\right)
\end{aligned}
$$


The end-of-period wealth $Y$ is a function of stochastic base wealth $Y$, stochastic output inventory $(\tilde{I}=L-D-S$ ) and $\operatorname{cash}(\mathrm{C})$,

$$
\begin{aligned}
& Y=\left(1+r_{Y}\right) Y_{0}+z_{Y} Y_{0} ; \\
& C=(1+r) C_{0} \\
& I=\left(1+r_{I}\right) I_{0}+z_{I} I_{0} ;
\end{aligned}
$$

Where

$$
\begin{aligned}
& r_{I} \equiv r_{L} \frac{L_{0}}{I_{0}}-r_{D} \frac{D_{0}}{I_{0}}-r_{S} \frac{S_{0}}{I_{0}} ; \\
& \tilde{z}_{I} \equiv \tilde{z}_{L} \frac{L_{0}}{I_{0}}-\tilde{z}_{D} \frac{D_{0}}{I_{0}}-\tilde{z} s \frac{S_{0}}{I_{0}}
\end{aligned}
$$

The expected rates of return on wealth are:

$$
\begin{aligned}
& r_{I}=r-\frac{1}{2} \frac{u^{\prime \prime}}{u^{\prime}} \sigma_{I Y} \\
& r_{w}=r_{Y} \frac{Y_{0}}{w_{0}}+r_{I} \frac{I_{0}}{w_{0}}+r \frac{C_{0}}{w_{0}}
\end{aligned}
$$

Expected utility of bank wealth is a linear function of equations (7-9):

$$
E U(w)=\lambda(b) \cdot(E q .7)+\lambda(a) \cdot(E q .8)+\lambda(c) \cdot(E q .9)
$$

Solving for the first-order conditions, we get the optimal value of $a, b$ and $c$.

$$
\begin{aligned}
& \frac{\partial E U(w)}{\partial b}=\beta(E q .7)+(\alpha-\beta b) u^{\prime}\left(w_{0}\right) Q=0 \\
& \frac{\partial E U(w)}{\partial a}=-\beta(E q .8)+(\alpha-\beta a+\vartheta c) u^{\prime}\left(w_{0}\right) Q+\vartheta(E q .9)=0 \\
& \frac{\partial E U(w)}{\partial c}=-\beta(E q .9)+(\alpha-\beta c+\vartheta a) u^{\prime}\left(w_{0}\right) Q+\vartheta(E q .7)=0
\end{aligned}
$$

We also assume the second order of deposit fees are negligible and get the margins.

$$
\begin{aligned}
& a+b=\frac{\alpha}{\beta}+\frac{1}{2} R \sigma_{I}^{2} Q \\
& a+c=\frac{\alpha}{\beta}+\frac{1}{2} R \sigma_{I}^{2}\left(Q+2 I_{0}\right)
\end{aligned}
$$

If we plug these results in Equation 3, the banks' spread is obtained as follows:

$$
s=a+b-(1-\rho)(a+c)=\rho\left(\frac{\alpha}{\beta}+\frac{1}{2} R \sigma_{I}^{2} Q\right)-(1-\rho) R \sigma_{I}^{2} I_{0}
$$

\section{Copyrights}

Copyright for this article is retained by the author(s), with first publication rights granted to the journal.

This is an open-access article distributed under the terms and conditions of the Creative Commons Attribution license which permits unrestricted use, distribution, and reproduction in any medium, provided the original work is properly cited. 